\title{
Partial and Total Solvent-Free Limonene's Hydrogenation: Metals, Supports, Pressure, and Water Effects
}

\author{
Fanta J. Ndongou Moutombi, ${ }^{1}$ Anne-Sylvie Fabiano-Tixier, ${ }^{2}$ Olivier Clarisse, ${ }^{1}$ \\ Farid Chemat $\mathbb{D}^{2},{ }^{2}$ and Mohamed Touaibia $\mathbb{D}^{1}$ \\ ${ }^{1}$ Department of Chemistry and Biochemistry, Université de Moncton, Moncton, NB, Canada \\ ${ }^{2}$ Université d'Avignon, INRA, UMR408, GREEN Extraction Team, F-84000 Avignon, France
}

Correspondence should be addressed to Mohamed Touaibia; mohamed.touaibia@umoncton.ca

Received 1 November 2019; Revised 4 February 2020; Accepted 10 March 2020; Published 1 April 2020

Academic Editor: Ioannis D. Kostas

Copyright (c) 2020 Fanta J. Ndongou Moutombi et al. This is an open access article distributed under the Creative Commons Attribution License, which permits unrestricted use, distribution, and reproduction in any medium, provided the original work is properly cited.

\begin{abstract}
Bio-based solvents menthene and menthane were obtained through limonene's partial and total hydrogenation under various catalytic conditions. Heterogeneous catalysts based on different active metals and supports (carbon, alumina, and silica) were systematically tested for solvent-free total and partial hydrogenation of limonene under high and low hydrogen pressure. Influences of these catalysts on the formation of menthene, menthane, and cymene, a dehydrogenated product, were determined. The impact of water addition on the conversion and selectivity of the catalysts was also investigated. Amongst all tested catalysts, $\mathrm{Rh}$ /Alumina which was never tested for total and partial hydrogenation of limonene was the most effective as 1-menthene was quantitatively produced at low pressure $(0.275 \mathrm{MPa})$ while menthane was mostly obtained at a higher pressure (2.75 MPa). Water addition on $\mathrm{Rh} /$ Alumina favoured menthene production even at high pressure. To propose menthane, menthene, and menthane/ menthene mixture as an alternative to fossil-based solvents such as $n$-hexane for the extraction of natural products, $\beta$-carotene, vanillin, and rosmarinic acid solubilizations have been investigated. If a modeling approach using COSMO-RS software predicted a comparable solubilization of these 3 compounds for the 3 solvents, experimental assays revealed that menthene solubilizes $\beta$-carotene, vanillin, and rosmarinic acid three to five times better than $n$-hexane.
\end{abstract}

\section{Introduction}

Nature wastes that were previously neglected are now recognized as precious materials. Plants, essential oils, and citrus peel constitute abundant and renewable biomasses with added value; they are inexpensive precursors that bring interesting properties to various industrial applications [1]. Limonene, a monocyclic terpene, and its hydrogenation products are part of this category of natural organic compounds. Nowadays, the literature reports several examples of the use of these products in pharmaceutical, cosmetics, food, and agrochemical processes $[2,3]$. Thus, research on the valorization of the limonene molecule, in particular by hydrogenation reactions, is of particular interest [4]. Indeed, the high reactivity of this molecule which can itself be a source of hydrogen makes its selective transformation difficult [5]. According to Augustine, the hydrogenation of limonene carbons corresponds to a type II selectivity, since it is possible to obtain two distinct products by two parallel reactions: $p$-menthene (product of the partial hydrogenation) and $p$-menthane (product of the total hydrogenation) starting from the same starting material $[6,7]$ (Scheme1).

$p$-Menthene, also known as carvomenthene, has been identified as an attractive building block for many chemicals such as pharmaceuticals, agrochemicals, perfumes, and bioplastic monomers $[8,9]$. The $p$-menthene's potential is due to the retention of the chiral centre and the intracyclic double bond that can be functionalized. $p$-Menthene has been used as a starting material for the synthesis of many practical products, such as endoperoxides and (-) menthol, widely used in pharmacy and in the development of pesticides [10-12]. $p$-Menthene is also used as a food scent in 


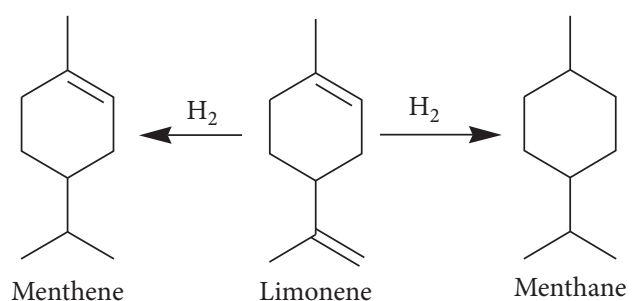

Scheme 1: Partial and total hydrogenation of limonene.

fruit juices and other food products and since a long time in glues, adhesives, and resin synthesis process $[13,14]$.

$p$-Menthane, which is a flavouring compound, is present for instance in peppermint [15]. This fully hydrogenated product has been shown to be a promising aviation biofuel and diesel fuel additive [16-19].

Starting from pure limonene without organic solvent or water, heterogeneous catalytic for total or partial hydrogenations has been previously reported: over Pd on porous glass catalyst system at room temperature and atmospheric pressure, menthane was obtained by Schmöger et al. with a $83 \%$ yield and a 95\% conversion of limonene [20]. Menthane was also synthetized over $\mathrm{Ni} / \gamma-\mathrm{Al}_{2} \mathrm{O}_{3}$ at $120^{\circ} \mathrm{C}$ [21]. Nickel loading of $21 \%$, calcination temperature of $550-650^{\circ} \mathrm{C}$, and hydrogen reduction temperature of $325-350^{\circ} \mathrm{C}$ were the optimum conditions for this gaseous phase hydrogenation. Over hydrido chlorocarbonyl tris-(triphenylphosphine) ruthenium (II) complex immobilized on amine functionalized MCM-41 and SBA-15, menthane was obtained by Joseph et al. at $60^{\circ} \mathrm{C}$ and 2.758 MPa of hydrogen pressure in acetonitrile [22].

Over catalyst prepared from $\mathrm{RhCl}_{3}$ and triphenylphosphine meta-trisulfonate in water, Larpent et al. achieved a $76 \%$ conversion of limonene into menthane [23]. In highpressure $\mathrm{CO}_{2}$ and over catalysts containing Pt and Pd [24], Bogel-Łukasik et al. also converted quantitatively limonene into menthane at $50^{\circ} \mathrm{C}$ under $4 \mathrm{MPa}$ of hydrogen pressure [25]. Partial hydrogenation of limonene to menthene tends to be problematic due to overreduction. Limonene hydrogenation using Wilkinson's catalyst confirmed that the hydrogenation of the endocyclic double bond is disfavored [26]. Following hydrogenation of limonene over $\mathrm{Pd} / \mathrm{C}$ and $\mathrm{Pd} /$ Alumina catalysts at room temperature and $0.1 \mathrm{MPa}$ of hydrogen pressure, side products, such as terpinolene, g-terpinene, and p-cymene, were formed besides menthene and menthane [27]. Partial hydrogenation of limonene to menthene, at low pressure, over Pt on Darco G-60 catalyst was reported by William [28]. Under mild conditions (room temperature and low pressure $(0.3 \mathrm{MPa})$ ), Rubulotta et al. compared $\mathrm{Pd}, \mathrm{Ru}$, and $\mathrm{Pt}$ over charcoal and alumina for limonene's partial hydrogenation. Over Pt/Alumina, menthene was obtained with excellent selectivity (90\%) and quantitative limonene's conversion after $5 \mathrm{~h}$. Under continuous flow conditions, Pt/C provided menthene (87\%) with a conversion of $96 \%$ [29]. While dehydrogenation can occur simultaneously on limonene carbonic cycle to generate cymene, there is no mention of the percentage of cymene detected in the previous two studies which ultimately will contaminate the menthene or the menthane formed.
In recent years, the role of water has received increasing attention, not only because of its presence in many chemical reactions, whether as a solvent or as an impurity (trace of moisture), but also because of its promotional or inhibiting effect of several transformations [30,31]. To the best of our knowledge and of the current literature, the hydrogenation of limonene over the commonly used catalysts, to obtain menthene or menthane, in the presence of water has never been investigated yet. On catalyst's surface molecular water, water clusters and dissociated products of water were detected using scanning tunneling microscopy [32-35]. The presence of water can be the source of hydrogen-bonded complexes as water is both a hydrogen bond donor and acceptor, which can accelerate hydrogen transfer and diffusion to promote subsequent hydrogenation or dehydrogenation [36]. Addition of small amounts of water in heterogeneous catalysis of natural products appears to improve selectivity and activate the catalyst as demonstrated by Yamaguchi et al. for the direct production of sugar alcohols from wood chips using supported platinum catalysts and also by Tike et al. for the hydrogenation of palm stearin fatty acid over ruthenium supported on alumina [37-39].

In this study, supported noble metals including $\mathrm{Pd}, \mathrm{Pt}, \mathrm{Ru}$, and $\mathrm{Rh}$, but also some less expensive and therefore more available metals such as nickel $(\mathrm{Ni})$ and copper $(\mathrm{Cu})$, were compared for partial and total hydrogenation of limonene. All hydrogenations were carried out at room temperature and low and high hydrogen pressure (0.275 $\mathrm{MPa}$ and $2.75 \mathrm{MPa})$. Conversion yield, dehydrogenation rate selectivity, and the influence of the catalyst support (carbon, alumina, and silica) as well as the presence of water in the reaction medium were investigated. Our hydrogenation experiments were also designed to investigate the hydrogenation of cymene, a contaminant for menthene and menthane but yet another added-value product, on the same catalysts.

\section{Materials and Methods}

Safety Warning. High-pressure experiments with compressed $\mathrm{H}_{2}$ (g) must be carried out only with appropriate equipment and under rigorous safety precautions.

2.1. General Experimental Conditions. Limonene and pcymene were purchased from Aldrich. $10 \mathrm{wt} . \% \mathrm{Pd} / \mathrm{C}$, 10 wt.\% Pd/Alumina, 5 wt.\% Pt/C, 5 wt.\% Pt/Alumina, 1 wt.\% Pt/Silica; 5 wt.\% Ru/C, 5 wt.\% Ru/Alumina; 5 wt.\% $\mathrm{Rh} / \mathrm{C}, 5$ wt.\% Rh/Alumina, 3 wt.\% Cu/C, and 65 wt.\% Ni/ Silica-Alumina were purchased from Aldrich. Pd/Silica "SiliaCat $\mathrm{Pd}(0)$ " was purchased from Silicycle Inc. $\mathrm{H}_{2}$ (purity $\geq 99.9 \%$ ) was purchased from Praxair Canada Inc. NMR spectra were recorded on Bruker Avance III $400 \mathrm{MHz}$ spectrometer. GC/MS analysis was recorded on an Agilent 6890 Series GC System coupled to an Agilent 5973 Network Mass Selective Detector and capillary column (Zebron ZB5MS, $30 \mathrm{~m} \times 0.25 \mathrm{~mm} \times 0.25 \mu \mathrm{m}$ ).

GC-MS analysis was recorded on an Agilent 6890 Series GC System coupled to an Agilent 5973 Network mass 
selective detector and capillary column (Zebron ZB-5MS, $30 \mathrm{~m} \times 0.25 \mathrm{~mm} \times 0.25 \mu \mathrm{m}$ ). Instrumentation settings for GC-MS analysis were as follows: samples were prepared with $15 \mathrm{ml}$ of hexane and $10 \mu \mathrm{l}$ of hydrogenated product. GC inlet was used in splitless mode at $280^{\circ} \mathrm{C}$. Ultrapure helium (Praxair grade 5.0) served as carrier gas at a constant flow rate of $0.8 \mathrm{~mL} / \mathrm{min}$. MS transfer line was set at $280^{\circ} \mathrm{C}$. MS source was held at $230^{\circ} \mathrm{C}$ while MS quad was set at $150^{\circ} \mathrm{C}$. MS performed scans from $\mathrm{m} / z$ 40-400. Ionization technique used was electron impact (EI). Automatic tune setting was used for the MS and tuning was performed before each sequence. GC was initially set at $40^{\circ} \mathrm{C}$, held for $0.5 \mathrm{~min}$, then temperature was ramped at $2^{\circ} \mathrm{C} / \mathrm{min}$ to $85^{\circ} \mathrm{C}$, and then ramped $40^{\circ} \mathrm{C} / \mathrm{min}$ to $300^{\circ} \mathrm{C}$ (total run time of $28.38 \mathrm{~min}$ ). Ten microliters of each sample were diluted in $15 \mathrm{~mL}$ hexane (Omnisolve grade from EMD Millipore) and $1 \mu \mathrm{L}$ of this solution was injected onto the GC-MS for analysis. Dodecane was tested as external and internal standard. From the total ion chromatogram (TIC) of pure standards of limonene, cymene, menthene, cis-menthane, and transmenthane, we have identified the retention time and the more appropriate $\mathrm{m} / \mathrm{z}$ ratio for each compound: $\mathrm{m} / \mathrm{z}$ of 136 at a retention time of $13.19 \mathrm{~min}$ was selected for limonene, $\mathrm{m} / \mathrm{z}$ of 134 at a retention time of $12.94 \mathrm{~min}$ was selected for cymene, $\mathrm{m} / \mathrm{z}$ of 138 at a retention time of $10.72 \mathrm{~min}$ was selected for menthene, $\mathrm{m} / \mathrm{z}$ of 140 at a retention time of $10.20 \mathrm{~min}$ was selected for cis-menthane, and $\mathrm{m} / z$ of 140 at a retention time of $10.95 \mathrm{~min}$ was selected for trans-menthane. For each sample, the previous $m / z$ ratios were extracted from the TIC to obtain the extracted ion chromatogram (EIC) and the corresponding peak area used for calculation.

All catalyst loadings specified by the commercial supplier were measured for verification by ICP/MS (see supplementary materials, Table S1). For each catalyst, $10 \mathrm{mg}$ was digested using $15 \mathrm{~mL}$ of aqua regia $\left(7: 3 \mathrm{v} / \mathrm{v} \mathrm{HCl} / \mathrm{HNO}_{3}\right.$, Trace metal grade, Fisher Scientific). Samples were heated at $75^{\circ} \mathrm{C}$ for 16 hours using a hot water bath. Catalyst digests were diluted to $50 \mathrm{~mL}$ using Milli-Q water (18.2- $\Omega \mathrm{M}$ grade water provided by an EMD Millipore water purification system, Darmstadt, Germany). Prior to be analyzed by ICP/ MS, catalyst digest samples were further diluted by a factor 1000. Dissolved metal concentrations into the limonene products were determined using the Thermo Scientific iCAP-Q inductively coupled plasma mass spectrometer (ICP/MS; Bremen, Germany) interfaced with the ASX-520 autosampler from CETAC Technologies (Omaha, USA). Prior to analysis, all samples were filtered using $0.45 \mu \mathrm{m}$ capsule filters (cellulose acetate membrane, VWR International) and then digested using aqua regia $(\sim 150 \mu \mathrm{L}$ of sample in $0.5 \mathrm{~mL}$ of $7: 3 \mathrm{v} / \mathrm{v} \mathrm{HCl} / \mathrm{HNO}_{3}$, Trace metal grade, Fisher Scientific). Samples were heated at $65^{\circ} \mathrm{C}$ for 4 hours using a hot water bath. Before analyses on the ICP/MS, $12 \mathrm{~mL}$ of Milli-Q water (18.2- $\Omega \mathrm{M}$ grade water provided by an EMD Millipore water purification system, Darmstadt, Germany) was added to each digest to reduce the sample matrix to a maximum of $4 \% \mathrm{v} / \mathrm{v}$ acid.

$\mathrm{N}_{2}$ adsorption-desorption isotherms and BET surface area were collected using a surface area and pore size analyzer (Quantachrome Autosorb-1 MP). Scanning electron microscopy (SEM) and energy dispersive X-ray spectroscopy (EDS) were performed with a field-emission scanning electron microscope (FE-SEM, Hitachi S-4800) equipped with an Oxford Inca x-stream EDS system (Oxford Instruments, High Wycombe). Images were collected using an accelerating voltage of $1.5 \mathrm{kV}$, while EDS spectra were collected at $15 \mathrm{kV}$. Transmission electron microscopy (TEM) was carried out on a JEOL JEM-1230 operating at $60-120 \mathrm{kV}$. The $\mathrm{H}_{2}$ chemisorption was determined via using a RXM-100 analyzer (ASDI) at $40^{\circ} \mathrm{C}$.

2.2. Hydrogenation of Limonene and Cymene. $2.5 \mathrm{~g}$ of limonene $(18.3 \mathrm{mmol})$ or $2.5 \mathrm{~g}$ of $p$-cymene $(18.6 \mathrm{mmol})$ and a catalyst $(\mathrm{Pd} / \mathrm{C}(10 \% \mathrm{wt}, 0.25 \mathrm{~g}, 0.23 \mathrm{mmol}, 0.01 \mathrm{eq}), \mathrm{Pd} / \mathrm{C}$ ( $10 \%$ wt, $0.125 \mathrm{~g}, 0.12 \mathrm{mmol}, 0.006 \mathrm{eq}$ ), $\mathrm{Pd} / \mathrm{C}$ (5\% wt, $0.25 \mathrm{~g}$, $0.12 \mathrm{mmol}, 0.006 \mathrm{eq}$ ), $\mathrm{Pd} / \mathrm{Al}_{2} \mathrm{O}_{3}(10 \% \mathrm{wt}, 0.234 \mathrm{mmol}, 0.006$ eq), $\mathrm{Pd} / \mathrm{Al}_{2} \mathrm{O}_{3}$ (10\% wt, $\left.0.125 \mathrm{~g}, 0.12 \mathrm{mmol}, 0.006 \mathrm{eq}\right), \mathrm{Pd} /$ $\mathrm{SiO}_{2}(0.22 \mathrm{mmol} / \mathrm{g}, 0.25 \mathrm{~g}, 0.05 \mathrm{mmol}, 0.003 \mathrm{eq}), \mathrm{Pt} / \mathrm{C}(5 \%$ wt, $0.5 \mathrm{~g}, 0.13 \mathrm{mmol}, 0.006 \mathrm{eq}$ ), Pt/C (5\% wt, $0.25 \mathrm{~g}$, $0.03 \mathrm{mmol}, 0.004 \mathrm{eq}$ ), $\mathrm{Pt} / \mathrm{Al}_{2} \mathrm{O}_{3}$ ( $5 \% \mathrm{wt}, 0.5 \mathrm{~g}, 0.13 \mathrm{mmol}$, $0.006 \mathrm{eq}$ ), $\mathrm{Pt} / \mathrm{Al}_{2} \mathrm{O}_{3}$ (5\% wt, $0.25 \mathrm{~g}, 0.03 \mathrm{mmol}, 0.004 \mathrm{eq}$ ), Pt/ $\mathrm{SiO}_{2}$ (1\% wt, $\left.0.25 \mathrm{~g}, 0.01 \mathrm{mmol}, 0.001 \mathrm{eq}\right), \mathrm{Ru} / \mathrm{C}(5 \% \mathrm{wt}$, $0.12 \mathrm{mmol}, 0.006 \mathrm{eq}$ ), $\mathrm{Ru} / \mathrm{Al}_{2} \mathrm{O}_{3}$ (5\% wt, $0.12 \mathrm{mmol}, 0.006$ eq), $\mathrm{Rh} / \mathrm{C}$ ( $5 \% \mathrm{wt}, 0.12 \mathrm{mmol}, 0.006 \mathrm{eq}$ ), or $\mathrm{Rh} / \mathrm{Al}_{2} \mathrm{O}_{3}$ (5\% wt, $0.12 \mathrm{mmol}, 0.006 \mathrm{eq})$ ) were added in a $45 \mathrm{~mL}$ in-house engineered stainless steel high-pressure autoclave equipped with a glass liner containing a stirring bar. The autoclave was purged four times with hydrogen $(1.37 \mathrm{MPa})$ and then pressurized to $0.275 \mathrm{MPa}$ or $2.75 \mathrm{MPa}$. Catalysts were not subjected to any treatment prior to hydrogenation. The reaction was stopped after no more change was monitored by GC/MS in the mixture percentage. Hydrogen was vented from the autoclave, and the reaction mixture was filtered through a celite pad to obtain the hydrogenated products. The disappearance of the vinylic or aromatic protons was confirmed by NMR. The final composition of the mixture was confirmed by GC/MS. Only menthene, menthane, and cymene were detected in our hydrogenation.

\subsection{Solubilization of Natural Products}

2.3.1. Computational Solubilization Prediction. Solubility abilities of cis-pinane, trans-pinane, cis-rich pinane (cis/ trans: $7 / 3$ ), and $n$-hexane to dissolve $\beta$-carotene, vanillin, and rosmarinic acid were investigated using COnductor-like Screening MOdel for Real Solvents (COSMO-RS) software. The results were expressed in $\log 10$ (x-solub) (best solubility is set to 0 ). The chemical structures of the solvents and solutes discussed in this article were mutually transformed by JChemPaint version 3.3 (GitHub Pages, San Francisco, CA, USA) to their simplified molecular input line entry syntax (SMILES) notations, which were subsequently used to calculate the solubility parameters.

2.3.2. Experimental Solubilization Assay. Solubilization by bead milling was performed using Precellys 24 (Bertin Technology, Ozyme) operating in a $2 \mathrm{~mL}$ tube with $1 \mathrm{~g}$ of 
ceramic beads. $100 \mathrm{mg}$ of compound was mixed with $1 \mathrm{~mL}$ of solvent and submitted in drive tube operating at $6500 \mathrm{rpm}$ during $2 * 20 \mathrm{sec}$. After extraction, the beads were filtered before solid/liquid separation by centrifugation. The samples were stored at $-20^{\circ} \mathrm{C}$ until analysis. All experiments were carried out in triplicates. The total content of each compound was measured spectrophotometrically (Biochrom Libra S22 $\mathrm{UV} / \mathrm{V}$ is Spectrophotometer) in a $1 \mathrm{~cm}$ optical path-length quartz cell at the maximum wavelength of each compound in each extract using DMSO as a blank. The Beer-Lambert law was used to determine the carotenoid, vanillin, and rosmarinic acid concentration in each extract using a calibration curve prepared using $\beta$-carotene, vanillin, and rosmarinic acid standard. The straight calibration curve of absorbance versus compound concentration $\left(\mathrm{mg} \cdot \mathrm{L}^{-1}\right)$ was reliant on the Beer-Lambert law. Finally, the quantity of compound dissolved in each solvent was calculated and expressed as $\mathrm{mg} \cdot \mathrm{L}^{-1}$.

\section{Results and Discussion}

3.1. Hydrogenation over $P d$. Palladium over carbon $(\mathrm{Pd} / \mathrm{C})$, one of the most used catalysts for hydrogenation, at high pressure converted limonene to the two menthane's isomers cis (19\%) and trans (81\%) exclusively with a large amount of cymene, which is due to the dehydrogenation of limonene (Table 1). If the addition of a small amount of water $(100 \mu \mathrm{L})$ had no effect on the limonene hydrogenation selectivity, it led to a significant decrease of cymene proportion and an increase of menthane. However, hydrogenation in the presence of a greater quantity of water $(5 \mathrm{~mL})$ inverted the reaction selectivity: 1-menthene became the major product (78\%) while a significant amount of cymene was still formed (53\%) [40].

At high pressure and in the absence solvent, $\mathrm{Pd} / \mathrm{Al}_{2} \mathrm{O}_{3}$ was less selective toward the menthane since $71 \%$ of menthene was obtained. The addition of a large amount of water provided only menthene with no trace of methene and $28 \%$ of cymene. $\mathrm{Pd} /$ Silica was selective for the hydrogenation of limonene to menthene. The proportion of menthane dropped considerably following the addition of a small amount of water since only $39 \%$ of menthene was obtained. The addition of more water completely deactivated this catalyst, the limonene was not hydrogenated, and no trace of cymene was detected.

At low pressure, the hydrogenation over palladium supported by the three supports was more favorable to the formation of the product of the partial hydrogenation with a longer reaction time in general. The addition of water, especially a large amount, increased the selectivity towards menthene but reduced the conversion rate of limonene to $85 \%$ with $\mathrm{Pd} / \mathrm{Al}_{2} \mathrm{O}_{3}$ and $\mathrm{Pd} /$ Silica. Even if the low-pressure hydrogenation with $\mathrm{Pd} /$ Alumina leads to menthene, the latter was completely hydrogenated after 6 hours of reaction. On the other hand, the presence of water seemed to prevent this double hydrogenation because even after $24 \mathrm{~h}$, menthane was not the major product.

3.2. Hydrogenation over Pt. Compared to $\mathrm{Pd} / \mathrm{C}, \mathrm{Pt} / \mathrm{C}$ was very selective for the formation of menthane with no trace of cymene and a very fast hydrogenation $(t \leq 4 \mathrm{~h})$. However, cis-menthane formation was favored since its proportion increased up to $44 \%$.

The addition of water, even in large quantities, had no effect on reactivity as well as selectivity since only menthane was obtained. Compared to $\mathrm{Pd} / \mathrm{Al}_{2} \mathrm{O}_{3}, \mathrm{Pt} / \mathrm{Al}_{2} \mathrm{O}_{3}$ was more selective towards the formation of menthene. The addition of a small amount of water increased this selectivity since only menthene was produced with no trace of cymene in only two hours of reaction. The addition of a large amount of water slowed the reaction with a slight decrease in the conversion and no effect on the selectivity. Like Pd/Silica, Pt/ Silica also favored menthene formation, but the addition of water, even in large quantities, did not impair its reactivity (Table 2). Similar to Pd, at low pressure, a partial hydrogenation of limonene was achieved on $\mathrm{Pt}$ over the three tested supports. Without water, Pt/Silica was the most selective toward menthene since limonene was converted to menthene with $93 \%$ of selectivity. $\mathrm{Pt} / \mathrm{C}$ and $\mathrm{Pt} / \mathrm{Al}_{2} \mathrm{O}_{3}$ lead, respectively, to 66 and $67 \%$ of menthene. On the other hand, the menthene obtained from the hydrogenation with $\mathrm{Pt} /$ $\mathrm{Al}_{2} \mathrm{O}_{3}$ was completely transformed into menthane after 6 hours of reaction. The addition of a small amount of water was the most efficient in the hydrogenation over $\mathrm{Pt} / \mathrm{Al}_{2} \mathrm{O}_{3}$ since this addition increased the reactivity and the percentage of menthene by $28 \%$. Even if the addition of a greater amount of water led exclusively to menthene, the activity of this catalyst is considerably reduced, especially for $\mathrm{Pt} / \mathrm{Si}$, with a conversion yield of less than $3 \%$. At high pressure, no trace of cymene was detected.

3.3. Hydrogenation over $\mathrm{Ru}$. Ru/C was much less effective than $\mathrm{Pd} / \mathrm{C}$ and $\mathrm{Pt} / \mathrm{C}$ for the partial or even total hydrogenation of limonene. No conversion of limonene was detected even after 24 hours of reaction. Adding a large amount of water only led to a $7 \%$ conversion of limonene. At low pressure, $\mathrm{Ru} / \mathrm{C}$ was completely inactive without and with the addition of water. $\mathrm{Ru} / \mathrm{Al}_{2} \mathrm{O}_{3}$ was more active than $\mathrm{Ru} / \mathrm{C}$, and limonene was converted to menthene $(87 \%)$ after $24 \mathrm{~h}$ of reaction. Catalyst support is therefore of prime importance for its activity. The addition of water reduced the selectivity and the reactivity since only $50 \%$ of limonene was hydrogenated in $24 \mathrm{~h}$ to menthene in presence of $5 \mathrm{~mL}$ of water. At low pressure, both Ru-based catalysts were completely inactive. Only $5 \%$ of limonene was converted to menthene with $\mathrm{Ru} / \mathrm{Al}_{2} \mathrm{O}_{3}$ in $24 \mathrm{~h}$. The addition of water had no effect on these two catalysts. Whether at high or low pressures, no trace of cymene was detected (Table 3).

3.4. Hydrogenation over $R h$. At high pressure, limonene was completely hydrogenated in menthane over $\mathrm{Rh} / \mathrm{C}$ in 2 hours. Only $4 \%$ of cymene was detected at the end of the reaction. The addition of water decreased the reducing capacity of this catalyst since $79 \%$ of menthene was obtained when the hydrogenation was conducted in the presence of a large amount of water. Compared to $\mathrm{Pd} / \mathrm{Al}_{2} \mathrm{O}_{3}$ and $\mathrm{Pt} / \mathrm{Al}_{2} \mathrm{O}_{3}, \mathrm{Rh}$ / $\mathrm{Al}_{2} \mathrm{O}_{3}$ was the most selective of the three catalysts for the hydrogenation of limonene to menthane with an equal 
TABLE 1: Hydrogenation of limonene over Pd.

\begin{tabular}{|c|c|c|c|c|c|c|c|c|}
\hline $\begin{array}{l}\text { Pressure } \\
(\mathrm{MPa})\end{array}$ & Support & $\mathrm{H}_{2} \mathrm{O}$ & $\begin{array}{c}\text { Conversion } \\
(\%)\end{array}$ & $\begin{array}{c}\text { Menthene/menthane } \\
(\%)\end{array}$ & $\begin{array}{c}\text { Cis/trans menthane } \\
(\%)\end{array}$ & Time $(\mathrm{h})$ & $\operatorname{TOF}_{b}\left(h^{-1}\right)$ & $\begin{array}{c}\text { Cymene } \\
(\%)\end{array}$ \\
\hline \multirow{9}{*}{2.75} & \multirow{3}{*}{ Carbon $^{\mathrm{b}}$} & - & 100 & $0 / 100$ & $19 / 81$ & 2 & 39 & 61 \\
\hline & & $100 \mu \mathrm{L}$ & 100 & $0 / 100$ & $26 / 74$ & 2 & 39 & 40 \\
\hline & & $5 \mathrm{~mL}$ & 100 & $78 / 21$ & $20 / 80$ & 4 & 18.5 & 53 \\
\hline & \multirow{3}{*}{$\mathrm{Al}_{2} \mathrm{O}_{3}{ }^{\mathrm{b}}$} & - & 100 & $71 / 29$ & $29 / 71$ & 2 & 39 & 28 \\
\hline & & $100 \mu \mathrm{L}$ & 100 & $69 / 31$ & $33 / 67$ & 2 & 39 & 15 \\
\hline & & $5 \mathrm{~mL}$ & 95 & $100 / 0$ & - & 6 & 12 & 28 \\
\hline & \multirow{3}{*}{ Silica $^{c}$} & - & 100 & $100 / 0$ & - & 4 & 19.5 & 14 \\
\hline & & $100 \mu \mathrm{L}$ & 100 & $39 / 61$ & $27 / 73$ & 2 & 39 & 0 \\
\hline & & $5 \mathrm{~mL}$ & 0 & - & - & 一 & - & - \\
\hline \multirow{9}{*}{0.275} & \multirow{4}{*}{ Carbon $^{\mathrm{b}}$} & - & 100 & $93 / 7$ & $37 / 63$ & 4 & 19.5 & 7 \\
\hline & & $100 \mu \mathrm{L}$ & 100 & $67 / 33$ & $25 / 75$ & 2 & 39 & 23 \\
\hline & & $5 \mathrm{~mL}$ & 100 & $100 / 0$ & - & 24 & 3.2 & 12 \\
\hline & & - & 100 & $78 / 18$ & $37 / 63$ & 2 & 39 & 4 \\
\hline & \multirow[t]{2}{*}{$\mathrm{Al}_{2} \mathrm{O}_{3}{ }^{\mathrm{b}}$} & $100 \mu \mathrm{L}$ & 100 & $91 / 9$ & $40 / 60$ & 2 & 39 & 6 \\
\hline & & $5 \mathrm{~mL}$ & 85 & $98 / 2$ & $41 / 59$ & 24 & 2.7 & 44 \\
\hline & \multirow{3}{*}{ Silica $^{c}$} & - & 100 & $96 / 4$ & $43 / 57$ & 6 & 13 & 2 \\
\hline & & $100 \mu \mathrm{L}$ & 100 & $98 / 2$ & $20 / 80$ & 4 & 19.5 & 2 \\
\hline & & $5 \mathrm{~mL}$ & 86 & $100 / 0$ & - & 24 & 2.8 & 28 \\
\hline
\end{tabular}

Experimental conditions: pure limonene, the catalyst, and room temperature. ${ }^{a}$ Turnover frequency (TOF) $=$ number of moles of consumed limonene/(mole of catalyst) time of reaction; ${ }^{\mathrm{b}} 10 \% \mathrm{wt} ;{ }^{\mathrm{c}} 0.2 \mathrm{mmol} / \mathrm{g}$.

TABle 2: Hydrogenation of limonene over Pt.

\begin{tabular}{|c|c|c|c|c|c|c|c|c|}
\hline $\begin{array}{l}\text { Pressure } \\
(\mathrm{MPa})\end{array}$ & Support & $\mathrm{H}_{2} \mathrm{O}$ & $\begin{array}{c}\text { Conversion } \\
(\%)\end{array}$ & $\begin{array}{c}\text { Menthene/menthane } \\
(\%)\end{array}$ & $\begin{array}{c}\text { Cis/trans menthane } \\
(\%)\end{array}$ & Time (h) & $\underset{a}{\text { TOF }}\left(h^{-1}\right)$ & $\begin{array}{c}\text { Cymene } \\
(\%)\end{array}$ \\
\hline \multirow{9}{*}{2.75} & \multirow{3}{*}{ Carbon $^{\mathrm{b}}$} & - & 100 & $0 / 100$ & $37 / 63$ & 2 & 143 & 0 \\
\hline & & $100 \mu \mathrm{L}$ & 100 & $0 / 100$ & $45 / 55$ & 4 & 71.5 & 0 \\
\hline & & $5 \mathrm{~mL}$ & 100 & $0 / 100$ & $36 / 64$ & 3 & 95.3 & 0 \\
\hline & \multirow{3}{*}{$\mathrm{Al}_{2} \mathrm{O}_{3}{ }^{\mathrm{b}}$} & - & 100 & $96 / 4$ & $48 / 52$ & 2 & 143 & 0 \\
\hline & & $100 \mu \mathrm{L}$ & 100 & $100 / 0$ & - & 2 & 143 & 0 \\
\hline & & $5 \mathrm{~mL}$ & 86 & $100 / 0$ & - & 24 & 10 & 0 \\
\hline & \multirow{3}{*}{ Silica $^{c}$} & - & 100 & $98 / 2$ & $39 / 61$ & 2 & 143 & 0 \\
\hline & & $100 \mu \mathrm{L}$ & 100 & $97 / 3$ & $31 / 69$ & 2 & 143 & 0 \\
\hline & & $5 \mathrm{~mL}$ & 100 & $86 / 14$ & $49 / 51$ & 4 & 71.5 & 0 \\
\hline \multirow{9}{*}{0.275} & \multirow{3}{*}{ Carbon $^{\mathrm{b}}$} & - & 100 & $67 / 33$ & $36 / 64$ & 24 & 12 & 0 \\
\hline & & $100 \mu \mathrm{L}$ & 100 & $70 / 30$ & $43 / 57$ & 6 & 48 & 0 \\
\hline & & $5 \mathrm{~mL}$ & 61 & $100 / 0$ & - & 6 & 29 & 0 \\
\hline & \multirow{3}{*}{$\mathrm{Al}_{2} \mathrm{O}_{3}{ }^{\mathrm{b}}$} & - & 73 & $66 / 7$ & $49 / 51$ & 2 & 104 & 0 \\
\hline & & $100 \mu \mathrm{L}$ & 100 & $94 / 6$ & $41 / 59$ & 6 & 48 & 0 \\
\hline & & $5 \mathrm{~mL}$ & 55 & $100 / 0$ & - & 24 & 6.5 & 0 \\
\hline & \multirow{3}{*}{ Silica $^{c}$} & - & 100 & $93 / 7$ & $45 / 55$ & 4 & 71.5 & 0 \\
\hline & & $100 \mu \mathrm{L}$ & 100 & $86 / 14$ & $47 / 53$ & 6 & 48 & 0 \\
\hline & & $5 \mathrm{~mL}$ & 3 & $100 / 0$ & - & 24 & 3.5 & 0 \\
\hline
\end{tabular}

Experimental conditions: pure limonene, the catalyst, and room temperature. ${ }^{\text {a }}$ Turnover frequency $(\mathrm{TOF})=$ number of moles of consumed limonene/(mole of catalyst) time of reaction; ${ }^{\mathrm{b}} 5 \% \mathrm{wt} ;{ }^{\mathrm{c}} 1 \% \mathrm{wt}$.

proportion of both cis- and trans-isomer. $\mathrm{Pt} / \mathrm{Al}_{2} \mathrm{O}_{3}$ and $\mathrm{Pd} /$ $\mathrm{Al}_{2} \mathrm{O}_{3}$ provide only $4 \%$ and $29 \%$ of menthane, respectively. Unlike $\mathrm{Pd}$ and $\mathrm{Pt}$, the addition of a small amount of water almost completely reversed the selectivity of $\mathrm{Rh} / \mathrm{Al}_{2} \mathrm{O}_{3}$ since menthene is the major product $(90 \%)$ with no trace of cymene. Hydrogenation in the presence of a greater amount of water increases the selectivity towards menthene to $100 \%$ but with a reduced limonene's conversion (70\%). At low pressure, the $\mathrm{Rh} / \mathrm{C}$ allowed partial hydrogenation of limonene to menthene $(88 \%)$ in addition to traces of cymene. Adding a small amount of water decreased the selectivity to $66 \%$. On the other hand, the hydrogenation in the presence of a greater quantity of water restored the selectivity to menthene but considerably reduced the reactivity of the catalyst since only $65 \%$ of the limonene was hydrogenated after $24 \mathrm{~h}$ of reaction (Table 4 ).

At low pressure, limonene was hydrogenated to menthene with $\mathrm{Rh} / \mathrm{Al}_{2} \mathrm{O}_{3}$ in 3 hours. The selectivity of this catalyst was clearly pressure-dependent. At high pressure, menthane was exclusively obtained with no traces of cymene. Menthene was solely obtained at reduced pressure with only $5 \%$ of cymene. Compared to $\mathrm{Rh} / \mathrm{C}$, the $\mathrm{Rh} / \mathrm{Alu}-$ mina selectivity's enhancement could be explained by mechanisms involving Lewis acid sites provided by alumina. 
TABle 3: Hydrogenation of limonene over Ru.

\begin{tabular}{|c|c|c|c|c|c|c|c|c|}
\hline Pressure $(\mathrm{MPa})$ & Support & $\mathrm{H}_{2} \mathrm{O}$ & $\begin{array}{c}\text { Conversion } \\
(\%)\end{array}$ & $\begin{array}{c}\text { Menthene/menthane } \\
(\%)\end{array}$ & $\begin{array}{c}\text { Cis/trans menthane } \\
(\%)\end{array}$ & $\begin{array}{l}\text { Time } \\
(\mathrm{h})\end{array}$ & $\underset{\mathrm{a}}{\mathrm{TOF}}\left(\mathrm{h}^{-1}\right)$ & $\begin{array}{c}\text { Cymene } \\
(\%)\end{array}$ \\
\hline \multirow{6}{*}{2.75} & \multirow{3}{*}{ Carbon $^{\mathrm{b}}$} & - & 0 & - & - & 24 & - & 0 \\
\hline & & $100 \mu \mathrm{L}$ & 0 & - & - & 24 & - & 0 \\
\hline & & $5 \mathrm{~mL}$ & 7 & $100 / 0$ & - & 24 & 0.4 & 0 \\
\hline & \multirow{3}{*}{$\mathrm{Al}_{2} \mathrm{O}_{3}{ }^{\mathrm{b}}$} & - & 100 & $87 / 13$ & $44 / 56$ & 24 & 6.2 & 0 \\
\hline & & $100 \mu \mathrm{L}$ & 80 & $71 / 9$ & $46 / 54$ & 24 & 4.9 & 0 \\
\hline & & $5 \mathrm{~mL}$ & 49 & $100 / 0$ & - & 24 & 3 & 0 \\
\hline \multirow{6}{*}{0.275} & \multirow{3}{*}{ Carbon $^{\mathrm{b}}$} & - & 0 & - & - & 24 & - & 0 \\
\hline & & $100 \mu \mathrm{L}$ & 0 & - & - & 24 & - & 0 \\
\hline & & $5 \mathrm{~mL}$ & 0 & - & - & 24 & - & 0 \\
\hline & \multirow{3}{*}{$\mathrm{Al}_{2} \mathrm{O}_{3}{ }^{\mathrm{b}}$} & - & 5 & $100 / 0$ & - & 24 & 0.3 & 0 \\
\hline & & $100 \mu \mathrm{L}$ & 0 & - & - & 24 & - & 0 \\
\hline & & $5 \mathrm{~mL}$ & 0 & - & - & 24 & - & 0 \\
\hline
\end{tabular}

Experimental conditions: pure limonene, the catalyst, and room temperature. ${ }^{\text {a }}$ Turnover frequency (TOF) $=$ number of moles of consumed limonene/(mole of catalyst) time of reaction; ${ }^{\mathrm{b}} 5 \% \mathrm{wt}$.

TABLE 4: Hydrogenation of limonene over Rh.

\begin{tabular}{|c|c|c|c|c|c|c|c|c|}
\hline Pressure $(\mathrm{MPa})$ & Support & $\mathrm{H}_{2} \mathrm{O}$ & Conversion (\%) & Menthene/menthane (\%) & $\begin{array}{c}\text { Cis/trans } \\
\text { menthane (\%) }\end{array}$ & Time (h) & $\begin{array}{l}\text { TOF } \\
\left(\mathrm{h}^{-1}\right)^{\mathrm{a}}\end{array}$ & Cymene (\%) \\
\hline \multirow{6}{*}{2.75} & \multirow{3}{*}{ Carbon $^{\mathrm{b}}$} & - & 100 & $0 / 100$ & $45 / 55$ & 2 & 75.5 & 4 \\
\hline & & $100 \mu \mathrm{L}$ & 100 & $61 / 39$ & $43 / 57$ & 2 & 75.5 & 0 \\
\hline & & $5 \mathrm{~mL}$ & 100 & $79 / 21$ & $49 / 51$ & 2 & 75.5 & 2 \\
\hline & \multirow{3}{*}{$\mathrm{Al}_{2} \mathrm{O}_{3}^{\mathrm{b}}$} & - & 100 & $0 / 100$ & $49 / 51$ & 5 & 30.2 & 0 \\
\hline & & $100 \mu \mathrm{L}$ & 100 & $90 / 10$ & $47 / 53$ & 1 & 151.2 & 0 \\
\hline & & $5 \mathrm{~mL}$ & 70 & $100 / 0$ & - & 6 & 17.6 & 0 \\
\hline \multirow{6}{*}{0.275} & \multirow{3}{*}{ Carbon $^{\mathrm{b}}$} & - & 100 & $88 / 12$ & $49 / 51$ & 6 & 25.2 & 5 \\
\hline & & $100 \mu \mathrm{L}$ & 100 & $66 / 34$ & $46 / 54$ & 4 & 37.8 & 0 \\
\hline & & $5 \mathrm{~mL}$ & 65 & $82 / 18$ & $32 / 68$ & 24 & 4.1 & 9 \\
\hline & \multirow{3}{*}{$\mathrm{Al}_{2} \mathrm{O}_{3}^{\mathrm{b}}$} & - & 92 & $100 / 0$ & - & 3 & 46.4 & 5 \\
\hline & & $100 \mu \mathrm{L}$ & 87 & $100 / 0$ & - & 4 & 32.8 & 0 \\
\hline & & $5 \mathrm{~mL}$ & 41 & $82 / 13$ & $31 / 69$ & 24 & 2.6 & 18 \\
\hline
\end{tabular}

Experimental conditions: pure limonene, the catalyst, and room temperature. ${ }^{\mathrm{a}}$ Turnover frequency (TOF) $=$ number of moles of consumed limonene/(mole of catalyst) time of reaction; ${ }^{b} 5 \%$ wt.

Lewis acidity of alumina support play an important role in many reactions, including hydrogenation [41, 42]. To detect Brönsted acidity of any dissolved material, $\mathrm{pH}$ measurement was carried out. Both the alumina support and the $\mathrm{Rh} / \mathrm{Al}_{2} \mathrm{O}_{3}$ have rather a neutral Brönsted-Lowry acid character since the measured $\mathrm{pH}$ was always in the neutral zone $(\mathrm{pH}=7.5-8.1)$. The addition of a small amount of water slightly reduced the reactivity without affecting the selectivity. However, the addition of more water significantly reduced the reactivity and selectivity while generating a greater amount of cymene.

3.5. Hydrogenation over $\mathrm{Ni}$ and $\mathrm{Cu}$. All of our attempts to hydrogenate limonene over $\mathrm{Cu} / \mathrm{C}$ catalyst failed: the addition of water as well as hydrogenation tests at $100^{\circ} \mathrm{C}$, with or without water, did not lead to any hydrogenation or dehydrogenation products. Over Ni/Silica-Alumina, it was possible to hydrogenate $95 \%$ of limonene in menthene $(63 \%)$ and menthane $(32 \%)$ at high pressure, $100^{\circ} \mathrm{C}$, and in the presence of a small amount of water in $24 \mathrm{~h}$ of reaction. Adding more water greatly reduced the reducing capacity since only $30 \%$ of limonene was hydrogenated to menthene only. At low pressure, Ni/Silica-Alumina reduction capacity decreased even further as $46 \%$ and $20 \%$ of the limonene was converted to menthene in the presence of a small and a large amount of water, respectively.

3.6. Catalyst Comparison. With the second higher TOF $\left(75 \mathrm{~h}^{-1}\right), \mathrm{Rh} / \mathrm{C}$ is a good catalyst for the conversion of limonene to menthane. This total hydrogenation of limonene was done in $2 \mathrm{~h}$ with $4 \%$ of cymene formed (Table 4 ). Larger pore volume, higher surface area, and nanoparticle size (Nps) of $\mathrm{Rh} / \mathrm{C}$ (pore volume: $0.7 \mathrm{~cm}^{3} / \mathrm{g}$, surface area: $815 \mathrm{~m}^{2} / \mathrm{g}$, and Nps: $0.93 \mathrm{~nm}$ ) might explain this higher activity when compared to $\mathrm{Rh} / \mathrm{Al}_{2} \mathrm{O}_{3}$ (pore volume: $0.4 \mathrm{~cm}^{3} / \mathrm{g}$, surface area: $150 \mathrm{~m}^{2} / \mathrm{g}$, and Nps: $0.76 \mathrm{~nm}$ ).

Like all the other catalysts tested, the two isomers of menthane (cis- and trans-menthane) were obtained with variable proportions but with a slight preference for the trans isomer. At high pressure and in the presence of a small amount of water, $\mathrm{Rh} / \mathrm{Al}_{2} \mathrm{O}_{3}$ was the most powerful catalyst $\left(\mathrm{TOF}=151 \mathrm{~h}^{-1}\right)$ for converting limonene mainly to menthene in just $2 \mathrm{~h}$.

Although it has a larger measured surface area than $\mathrm{Rh} /$ $\mathrm{Al}_{2} \mathrm{O}_{3}\left(150 \mathrm{~m}^{2} / \mathrm{g}\right), \mathrm{Rh} / \mathrm{C}\left(815 \mathrm{~m}^{2} / \mathrm{g}\right)$ performs less than $\mathrm{Rh} /$ $\mathrm{Al}_{2} \mathrm{O}_{3}$ in the presence of water for synthesis of the partial 
hydrogenation product. Measured pore diameter difference $\left(\mathrm{Rh} / \mathrm{Al}_{2} \mathrm{O}_{3}: 74.4 \mathrm{Ao}, \mathrm{Rh} / \mathrm{C}: 10.8 \mathrm{Ao}\right)$ may explain this performance disparity. Additionally, from SEM images (see supplementary materials, Figures S1 and S2), it can be observed that the particles of $\mathrm{Rh} / \mathrm{C}$ were agglomerated/ sintered which could explain its weaker activity compared to $\mathrm{Rh} / \mathrm{Al}_{2} \mathrm{O}_{3}$. Over alumina, $\mathrm{Rh}$ had a larger catalytic surface area $\left(150 \mathrm{~m}^{2} / \mathrm{g}\right)$ and a larger nanoparticles size (Nps $\left.16 \mathrm{~nm}\right)$ than those of Pt and Ru $[29,43]$.

A larger promoter effect of water combined with the large difference in size of $\mathrm{Rh}$ nanoparticles on these two supports might explain this difference.

$\mathrm{Rh} /$ Alumina which was never tested for total and partial hydrogenation of limonene was the most effective as menthene was quantitatively produced at low pressure $(0.275 \mathrm{MPa})$ while menthane was mostly obtained at a higher pressure $(2.75 \mathrm{MPa})$. Water addition on $\mathrm{Rh} /$ Alumina favoured menthene production even at high pressure (Table 4).

Alumina Lewis acidic character as well as water effect can explain these results. More tests, in particular on catalysts after hydrogenation, will be necessary to elucidate the watercatalyst interactions.

Investigation of limonene's hydrogenation with the selected catalysts revealed that limonene's partial hydrogenation is pressure-dependent. At low pressure, all catalysts, except $\mathrm{Ru}$, independent of the supports were menthene selective. It was reported that hydrogenation of the limonene's endocyclic double bond was disfavored compared to the exocyclic double bond's hydrogenation [26]. It was also reported that $\mathrm{Ru} / \mathrm{C}$ has smallest nanoparticles $(1.5 \mathrm{~nm})$, compared to the other investigated metals, which could explain its inactivity on our hydrogenation [29].

3.7. $\mathrm{Rh} / \mathrm{Al}_{2} \mathrm{O}_{3}$ Recycling and Kinetic Studies. Based on our results, we selected $\mathrm{Rh} / \mathrm{Al}_{2} \mathrm{O}_{3}$ for further recycling tests and kinetic studies. $\mathrm{Rh} /$ Alumina was the best switchable catalyst with a higher selectivity toward 1-menthene in the presence of a small amount of water. The same catalyst, without the addition of water, led exclusively to menthane with no traces of cymene. To the best of our knowledge, this catalyst has never been tested for the solvent-free hydrogenation of limonene and the effect of pressure and water addition on the selectivity has never been investigated. The absence of cymene during the hydrogenation of limonene with this catalyst compared to the most common catalysts used for hydrogenation has never been investigated as well.

At high pressure and after one hour of reaction over $\mathrm{Rh} /$ Alumina, all limonene was converted into a mixture of menthene and menthane $(1: 1)$. During the remaining 5 hours of reaction, menthene was gradually converted into menthane (Figure 1).

At high pressure and in the presence of water, after about one hour of hydrogenation over Rh/Alumina, limonene was also almost completely converted into menthene (Figure 2). Menthane began to be produced in small proportion after 30 minutes of reaction. Hydrogenation of limonene remained therefore partial since the proportion of menthene continued to increase between 30 and 40 minutes of hydrogenation.

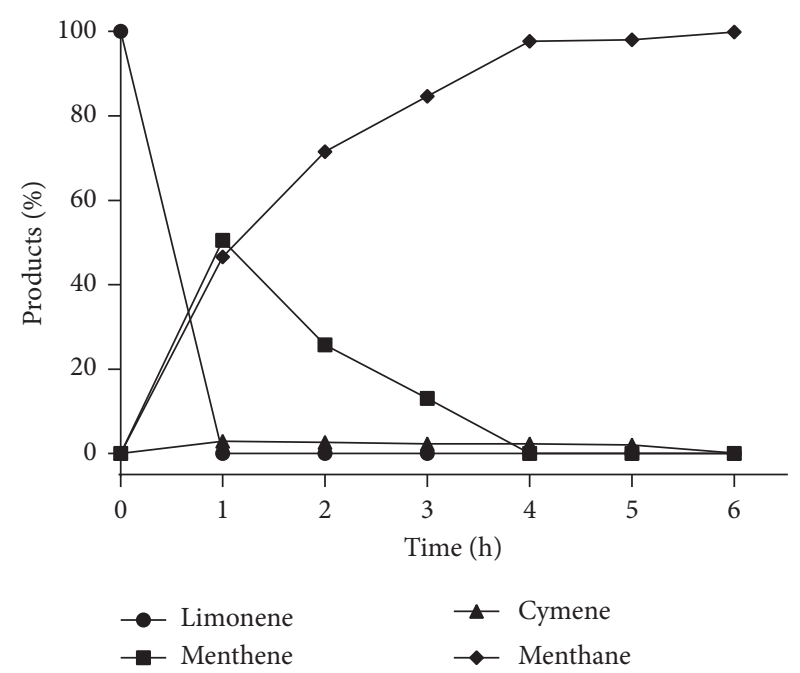

Figure 1: Hydrogenation of limonene over $5 \%$ wt $\mathrm{Rh} / \mathrm{Al}_{2} \mathrm{O}_{3}$, $2.75 \mathrm{MPa}$, and room temperature.

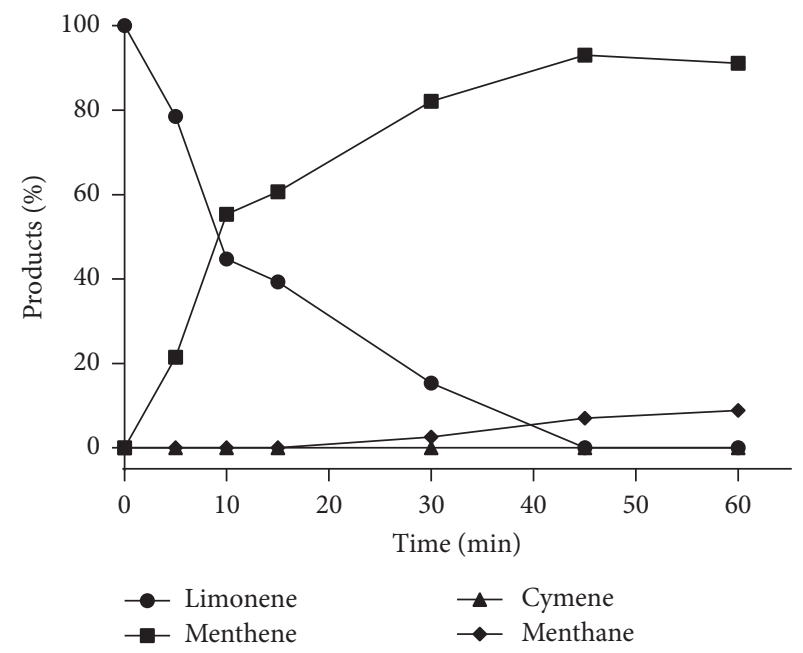

Figure 2: Hydrogenation of limonene over $5 \%$ wt $\mathrm{Rh} / \mathrm{Al}_{2} \mathrm{O}_{3}$, $2.75 \mathrm{MPa}$, and room temperature in the presence of water $(100 \mu \mathrm{L})$.

The low proportion of the menthane formed after 45 minutes of reaction could also be attributed to menthene's own hydrogenation: a $10 \%$ proportion of menthane was achieved once limonene was completely converted and remained unchanged even after several hours of reaction.

The potential to recycle $\mathrm{Rh} /$ Alumina was tested by repeatedly by adding fresh limonene into the reactor vessel once the hydrogenation of each cycle was complete. In presence of $100 \mu \mathrm{l}$ of water, $\mathrm{Rh} /$ Alumina was reused successfully 7 times with no decline in activity (Table 5).

Without addition of water, $\mathrm{Rh} / \mathrm{Al}_{2} \mathrm{O}_{3}$ provided menthane (44/56 cis/trans) exclusively in the first cycle, but becomes highly selective towards menthene from the second cycle: limonene's hydrogenation over the recycled catalyst lead after $2 \mathrm{~h}$ to a complete conversion of limonene into $85 \%$ of menthene and only $15 \%$ of menthane. 
TABLe 5: Recyclability of $\mathrm{Rh} / \mathrm{Al}_{2} \mathrm{O}_{3}$ (5\% wt).

\begin{tabular}{|c|c|c|c|}
\hline Cycles & Conversion (\%) & $\begin{array}{c}\text { Menthene/menthane } \\
(\%)\end{array}$ & $\begin{array}{c}\text { Cis/trans } \\
\text { menthane (\%) }\end{array}$ \\
\hline \multicolumn{4}{|c|}{$\mathrm{Rh} / \mathrm{Al}_{2} \mathrm{O}_{3}+100 \mu \mathrm{l} \mathrm{H}{ }_{2} \mathrm{O}(2.75 \mathrm{MPa})$} \\
\hline 1 & 100 & $90 / 10$ & $49 / 51$ \\
\hline 2 & 100 & $90 / 10$ & $50 / 50$ \\
\hline 3 & 100 & $90 / 10$ & $48 / 52$ \\
\hline 4 & 100 & $90 / 10$ & $49 / 51$ \\
\hline 5 & 100 & $89 / 11$ & $48 / 52$ \\
\hline 6 & 100 & $94 / 6$ & $46 / 54$ \\
\hline 7 & 100 & $93 / 7$ & $44 / 56$ \\
\hline \multicolumn{4}{|c|}{$\mathrm{Rh} / \mathrm{Al}_{2} \mathrm{O}_{3}(2.75 \mathrm{MPa})$} \\
\hline 1 & 100 & $0 / 100$ & $44 / 56$ \\
\hline 2 & 100 & $85 / 15$ & $45 / 55$ \\
\hline 3 & 100 & $94 / 6$ & $47 / 53$ \\
\hline 4 & 91 & $95 / 5$ & $43 / 57$ \\
\hline 5 & 77 & $97 / 3$ & $33 / 67$ \\
\hline
\end{tabular}

Experimental conditions: pure limonene, the catalyst, and room temperature.

The menthene selectivity increased significantly from $85 \%$ to $97 \%$ after the third run (Table 5). This decrease in the strength of this catalyst, even in the absence of water, can be exploited perfectly for the production of menthene. After reducing its strength, with a first hydrogenation, $\mathrm{Rh} / \mathrm{Al}_{2} \mathrm{O}_{3}$ can be used for 4 cycles for the production of an enriched mixture of menthene.

To confirm the heterogeneous nature of the catalysis, $\mathrm{Rh}$ leached from the Rh/Alumina catalyst into the menthene or menthane solution was measured by ICP/MS: it never exceeded $0.002 \%$ of the initial $\mathrm{Rh}$ amount. When $\mathrm{Rh} / \mathrm{Al}_{2} \mathrm{O}_{3}$ was filtered after half-time reaction, the hydrogenation of the filtrate without the filtered catalyst, at the same hydrogen pressure and temperature, failed even after $24 \mathrm{~h}$ of reaction, which confirmed the lack of Rh catalyst in the filtrate and the heterogeneous catalytic nature of the reaction.

3.8. Cymene Hydrogenation Investigation. The absence of cymene in our limonene's hydrogenations over Rh may be due to either the non-dehydrogenation of the limonene or to the hydrogenation of the generated cymene. It is the main reason that why cymene hydrogenation was investigated with all tested catalysts in this study. Cymene hydrogenation over only $\mathrm{Pd} / \mathrm{C}$ has been investigated by Stalzer et al. for comparison with the single-face arene hydrogenation by a supported organozirconium catalyst [44].

With $\mathrm{Pd}$, only $\mathrm{Pd} / \mathrm{C}$ allows a very slow hydrogenation of cymene to menthane. No conversion to menthane was observed over $\mathrm{Rh} / \mathrm{Al}_{2} \mathrm{O}_{3}$ or $\mathrm{Pd} /$ Silica even after $24 \mathrm{~h}$ of reaction and under high pressure (2.75 MPa) (Table 6). Ru was more effective for cymene's hydrogenation than limonene. Under high pressure and at room temperature, cymene was completely hydrogenated to menthane in $5 \mathrm{~h}$ (Table 6).

The hydrogenation of cymene over Pt was more efficient than over Pd since a conversion of almost all cymene was observed after 24 hours of reaction (Table 6). Rh was the most efficient of all tested catalysts since either over $\mathrm{Rh} / \mathrm{C}$ or $\mathrm{Rh} / \mathrm{Al}_{2} \mathrm{O}_{3}$, the cymene was hydrogenated to methane in only
TABLE 6: Hydrogenation of cymene (2.75 MPa, rt) to menthane.

\begin{tabular}{lccccc}
\hline Metal & Support & $\begin{array}{c}\text { Conversion } \\
(\%)\end{array}$ & $\begin{array}{c}\text { Cis/Trans } \\
(\%)\end{array}$ & $\begin{array}{c}\text { Time } \\
(\mathrm{h})\end{array}$ & $\begin{array}{c}\text { TOF } \\
\left(\mathrm{h}^{-1}\right)^{\mathrm{a}}\end{array}$ \\
\hline \multirow{3}{*}{$\mathrm{Pd}$} & $\mathrm{Carbon}^{\mathrm{b}}$ & 5 & $35 / 65$ & 24 & 0.2 \\
& $\mathrm{Al}_{2} \mathrm{O}_{3}{ }^{\mathrm{b}}$ & 0 & - & 24 & - \\
& $\mathrm{Silica}^{\mathrm{c}}$ & 0 & - & 24 & - \\
\hline \multirow{4}{*}{$\mathrm{Pt}$} & $\mathrm{Carbon}^{\mathrm{d}}$ & 94 & $68 / 32$ & 24 & 11 \\
& $\mathrm{Al}_{2} \mathrm{O}_{3}{ }^{\mathrm{b}}$ & 85 & $58 / 42$ & 24 & 10 \\
& $\mathrm{Silica}^{\mathrm{e}}$ & 79 & $61 / 39$ & 24 & 9 \\
\hline \multirow{2}{*}{$\mathrm{Ru}$} & $\mathrm{Carbon}^{\mathrm{d}}$ & 100 & $65 / 35$ & 5 & 30 \\
& $\mathrm{Al}_{2} \mathrm{O}_{3}{ }^{\mathrm{b}}$ & 82 & $67 / 33$ & 24 & 5 \\
\hline \multirow{2}{*}{$\mathrm{Rh}$} & $\mathrm{Carbon}^{\mathrm{d}}$ & 100 & $69 / 31$ & 1 & 151 \\
& $\mathrm{Al}_{2} \mathrm{O}_{3}{ }^{\mathrm{b}}$ & 100 & $68 / 32$ & 1 & 151 \\
\hline
\end{tabular}

Experimental conditions: pure cymene, the catalyst, and room temperature. ${ }^{a}$ Turnover frequency $($ TOF $)=$ number of moles of consumed cymene $/($ mole of catalyst) time of reaction; ${ }^{\mathrm{b}} 10 \% \mathrm{wt} ;{ }^{\mathrm{c}} 0.2 \mathrm{mmol} / \mathrm{g} ;{ }^{\mathrm{d}} 5 \% \mathrm{wt} ;{ }^{\mathrm{e}} 1 \% \mathrm{wt}$.

1 hour. Over the same catalysts, hydrogenation of a mixture $(1: 1)$ of limonene and cymene provided only menthane without any trace of menthene and cymene. As with all other catalysts, menthane was obtained in its cis 42\%) and trans isomers (Table 6). Except over $\mathrm{Pd} / \mathrm{C}$, all of the other catalysts gave more cis-isomer than trans-isomer.

As for limonene hydrogenation, Rh leaching from $\mathrm{Rh} /$ $\mathrm{Al}_{2} \mathrm{O}_{3}$ catalyst into the cymene solution was measured by ICP/MS: it never exceeded $0.001 \%$ of the initial Rh amount. When $\mathrm{Rh} / \mathrm{Al}_{2} \mathrm{O}_{3}$ was filtered after half-time reaction, the hydrogenation of the filtrate without the filtered catalyst, at the same hydrogen pressure and temperature, failed even after $24 \mathrm{~h}$ of reaction, which confirmed the lack of Rh catalyst in the filtrate and the heterogeneous catalytic nature of the reaction.

3.9. Solubilization Assays. Menthene and menthane, obtained from limonene, were tested as a bio-based alternative solvent for the solubilization of various natural products such as carotenoids, vanillin, and rosmarinic acid. As predicted by COSMO-RS, menthene and menthane showed similar probability of solubility as $n$-hexane of all analyzed compounds (Table 7). Menthene as well as menthane showed high probability of solubility of $\beta$-carotene and vanillin rather than rosmarinic acid.

Experimentally, the solubility of $\beta$-carotenoids, vanillin, and rosmarinic acid in obtained menthene and menthane as solvents was investigated by bead milling. Menthene appeared to be the best solvent; it solubilized $\beta$-carotene, vanillin, and rosmarinic acid three to five times better than $n$-hexane (Table 8).

Pure menthane, obtained following cymene's hydrogenation, solubilized $\beta$-carotene twice better than $n$-hexane. On the other hand, it was quite equivalent to $n$-hexane for the solubilization of vanillin and rosmarinic acid (Table 8). The presence of the carbon-carbon double bond of menthene seemed to be crucial for the solubilization capacity of selected molecules. The presence of only $2 \%$ of menthene in the menthane obtained after limonene's total hydrogenation seems to increase its solubilization capacities. 
TABLE 7: COSMO-RS relative solubility $(\log 10(\mathrm{x}$-solub)) of $\beta$-carotenoids, vanillin, and rosmarinic acid in $n$-hexane, menthene, and menthane.

\begin{tabular}{lccc}
\hline Compounds & $n$-Hexane $(\log 10(\mathrm{x}$-solub $))$ & Menthene $(\log 10(\mathrm{x}$-solub $))$ & Menthane $(\log 10(\mathrm{x}$-solub) \\
\hline$\beta$-Carotene & -0.0087 & 0.0 & 0.0 \\
Vanillin & -2.499 & -2.129 & -2.516 \\
Rosmarinic acid & -9.099 & -8.083 & -9.140 \\
\hline
\end{tabular}

TABLE 8: $\beta$-Carotene, vanillin, and rosmarinic acid solubility in $n$-hexane, menthene, and menthane.

\begin{tabular}{lccc}
\hline Solvent & $\beta$-Carotene solubility $\left(\mathrm{mg} \cdot \mathrm{mL}^{-1}\right)$ & Vanillin solubility $\left(\mathrm{mg}^{\left.\mathrm{m} L^{-1}\right)}\right.$ & Rosmarinic acid solubility $\left(\mathrm{mg} \cdot \mathrm{mL}^{-1}\right)$ \\
\hline$n$-hexane & $0.99 \pm 0.06$ & $1.19 \pm 0.09$ & $0.54 \pm 0.01$ \\
Menthene/menthane: (90/10) & $3.55 \pm 0.10$ & $6.07 \pm 0.24$ & $2.11 \pm 0.18$ \\
Pure menthane & $2.85 \pm 0.14$ & $1.03 \pm 0.14$ & $0.33 \pm 0.04$ \\
Menthane/menthene (98/2) & $3.53 \pm 0.18$ & $6.95 \pm 0.18$ & $0.65 \pm 0.04$ \\
\hline
\end{tabular}

As presented in Table 8, menthane containing $2 \%$ of menthene solubilized three and five times better than $n$ hexane $\beta$-carotene and vanillin, respectively. This same mixture becomes equivalent to $n$-hexane for the solubilization of rosmarinic acid (Table 8).

\section{Conclusion}

Partial and total solvent-free hydrogenation of limonene was investigated using commercially available catalysts under high and low hydrogen pressure with or without water. Compared to palladium, ruthenium, platinum, nickel, and copper, Rh was an excellent catalyst for the hydrogenation of limonene to menthene and menthane. Over Rh/Alumina, menthane, the product of total hydrogenation, was obtained solely at high pressure with a turnover number around 150 .

At high pressure and with the same catalyst but in the presence of a small amount of water, there is a reversal of the selectivity since menthene became the major product. The addition of water reverses only the selectivity in the hydrogenation of limonene's hydrogenation over Rh, since this inversion is not observed with the other tested catalysts. This inversion is much more important over $\mathrm{Rh} /$ Alumina than with $\mathrm{Rh} / \mathrm{C}$.

At low pressures, the conversion of limonene was either not complete or the selectivity did not reach $90 \%$ in menthene and the reaction was too slow. In terms of recyclability, $\mathrm{Rh}$ /Alumina, with the addition of water, was recycled 7 times with no decline in selectivity and activity. The same catalyst, after the first run, was recycled 5 times with no decline in selectivity and activity. Rh has been found to be the best catalyst for cymene's hydrogenation compared to the six tested metals. Over $\mathrm{Rh} / \mathrm{C}$ or $\mathrm{Rh} /$ Alumina, cymene was efficiently converted into menthane exclusively in only one hour. $\mathrm{Rh} / \mathrm{C}$ and $\mathrm{Rh} /$ Alumina were recycled 6 and 5 times, respectively, with no decline in activity.

Compared to $n$-hexane, menthene solubilized more $\beta$-carotene, vanillin, and rosmarinic acid. Consequently, menthene, as well as menthane containing menthene, could be interesting bio-based solvents to replace fossil-based solvents such as $n$-hexane for the extraction of several natural products widely used in many industries.

\section{Data Availability}

The data used to support the findings of this study are included within the article.

\section{Conflicts of Interest}

The authors declare that there are no conflicts of interest.

\section{Acknowledgments}

The authors would like to acknowledge the contribution of the New Brunswick Innovation Foundation (grant no. RIF2015-014 to M.T.) and the Canadian Foundation for Innovation (Leaders Opportunity Fund (grant no. 17996 to M.T.)). The authors thank Dr. Y. Djaoued, R. Cormier, N. A. Levesque, J. Robichaud, M. Jebali, and A. Landry for their support for the catalyst characterizations. The authors also thank Dr. A. Nait Ajjou for sharing his autoclave and Dr. Simon Lamarre for sharing his GC-MS.

\section{Supplementary Materials}

Table S1: catalyst loadings measured by ICP/MS. Table S2: Rh-based catalyst features. Figure 1S: Rh/C particle size distribution measured by TEM. Figure $2 \mathrm{~S}$ : Rh/Alumina particle size distribution measured by TEM. (Supplementary Materials)

\section{References}

[1] S. Tanielyan, N. Biunno, R. Bhagat, and R. Augustine, "Anchored Wilkinson catalyst: hydrogenation of $\beta$ pinene," Topics in Catalysis, vol. 57, no. 17-20, pp. 1564-1569, 2014.

[2] M. Aissou, Z. Chemat-Djenni, E. Yara-Varón, A. FabianoTixier, and F. Chemat, "Limonene as an agro-chemical building block for the synthesis and extraction of bioactive compounds," Comptes Rendus Chimie, vol. 11, no. 20, pp. 346-358, 2017.

[3] L. Xie, X. Wang, F. Yu, B. Yuan, C. Xie, and S. Yu, "Preparation of cis-pinane via $\alpha$-pinene hydrogenation in water by using $\mathrm{Ru}$ nanoparticles immobilized in functionalized amphiphilic mesoporous silica," RSC Advances, vol. 7, no. 81, pp. 51452-51459, 2017. 
[4] E. Yllmazoğlu and M. Akgün, " $p$-Cymene production from orange peel oil using some metal catalyst in supercritical alcohols," The Journal of Supercritical Fluids, vol. 131, pp. 37-46, 2018.

[5] H. Cui, J. Zhang, Z. Luo, and C. Zhao, "Mechanisms into dehydroaromatization of bio-derived limonene to $p$-cymene over Pd/HZSM-5 in the presence and absence of $\mathrm{H}_{2}, "$ RSC Advances, vol. 6, no. 71, pp. 66695-66704, 2016.

[6] R. Augustine, Heterogeneous Catalysis for the Synthetic Chemist, CRC Press, New York, NY, USA, 1996.

[7] F. Zaccheria and N. Ravasio, "Catalytic reduction in organic synthesis," Science of Synthesis, vol. 1, p. 111, 2017.

[8] R. Mathers and M. Meier, Green Polymerization Methods, Wiley VCH, Weinheim, Gremany, 2011.

[9] M. Golets, S. Ajaikumar, and J.-P. Mikkola, "Catalytic upgrading of extractives to chemicals: monoterpenes to "EXICALS"" Chemical Reviews, vol. 115, no. 9, pp. 3141-3169, 2015.

[10] I. Pérez and J. G. Ávila-Zárraga, "Synthesis of puleganic amides via a catalytically efficient two-step approach," Tetrahedron Letters, vol. 59, no. 32, pp. 3077-3079, 2018.

[11] S. Selifonov, "Methods for making (-)-menthol and oxygenated menthane compounds," US Patent US2003/023120, 2006.

[12] C. Daeppen, M. Kaiser, M. Neuburger, and K. Gademann, "Preparation of antimalarial endoperoxides by a formal [2+2+2] cycloaddition," Organic Letters, vol. 17, no. 21, pp. 5420-5423, 2015.

[13] S. Schoenauer and P. Schieberle, "Structure-odor activity studies on monoterpenoid mercaptans synthesized by changing the structural motifs of the key food odorant 1-pMenthene-8-thiol," Journal of Agricultural and Food Chemistry, vol. 64, no. 19, pp. 3849-3861, 2016.

[14] C. Nancy and J. B. Jeffrey, "Modified creping adhesive composition and method of use thereof," US Patent 7404875B2, 2008.

[15] R. Rios-Estepa, G. W. Turner, J. M. Lee, R. B. Croteau, and B. M. Lange, "A systems biology approach identifies the biochemical mechanisms regulating monoterpenoid essential oil composition in peppermint," Proceedings of the National Academy of Sciences, vol. 105, no. 8, pp. 2818-2823, 2008.

[16] V. K. Bhatia, K. G. Mittal, R. P. Mehrotra, and M. Mehrotra, "Hydrocarbon fuels from biomass," Fuel, vol. 68, no. 4, pp. 475-479, 1989.

[17] N. I. Tracy, D. Chen, D. W. Crunkleton, and G. L. Price, "Hydrogenated monoterpenes as diesel fuel additives," Fuel, vol. 88, no. 11, pp. 2238-2240, 2009.

[18] J. L. Kuester, "Liquid hydrocarbon fuels from biomass," ACS Symposium Series, vol. 144, no. 8, pp. 163-184, 1981.

[19] M. A. Fraga, L. Borges, and F. R. Gonçalves, "Catalytic process of limonene hydrogenation for producing $p$-Menthane and use of the $p$-Menthane produced as aviation biofuel," WO Patent 2012012856 A1, 2012.

[20] C. Schmöger, A. Stolle, W. Bonrath et al., "A practical approach for ambient-pressure hydrogenations using $\mathrm{Pd}$ on porous glass," ChemSusChem, vol. 2, no. 1, pp. 77-82, 2009.

[21] C. B. Dai, G. F. Pan, R. D. Li, and H. Wang, "The study on dipentene hydrogenation catalyst," Advanced Materials Research, vol. 550-553, pp. 371-374, 2012.

[22] J. Trissa, S. S. Deshpande, S. B. Halligudi, A. Vinu, S. Ernst, and M. Hartmann, "Hydrogenation of olefins over hydrido chlorocarbonyltris-(triphenylphosphine) ruthenium (II) complex immobilized on functionalized MCM-41 and SBA15," Journal of Molecular Catalysis A: Chemical, vol. 206, no. 1-2, pp. 13-21, 2003.
[23] L. Chantal, D. René, and P. Henri, "Catalytic hydrogenation of olefins in biphasic mater-liquid system," Tetrahedron Letters, vol. 28, no. 22, pp. 2507-2510, 1987.

[24] E. Bogel-Łukasik, I. Fonseca, R. Bogel-Łukasik et al., "Phase equilibrium-driven selective hydrogenation of limonene in high-pressure carbon dioxide," Green Chemistry, vol. 9, no. 5, pp. 427-430, 2007.

[25] E. Bogel-Łukasik, R. Bogel-Łukasik, and M. Nunes da Ponte, "Effect of flow rate of a biphasic reaction mixture on limonene hydrogenation in high pressure $\mathrm{CO}_{2}$," Industrial \& Engineering Chemistry Research, vol. 48, no. 15, pp. 7060-7064, 2009.

[26] S. K. Tanielyan, R. L. Augustine, N. Marin, and G. Alvez, "Anchored Wilkinson catalyst," ACS Catalysis, vol. 1, no. 2, pp. 159-169, 2011.

[27] J. G. Ricardo, D. Z. Patricia, G. Carolina, and A. T. Hugo, "Liquid phase hydrogenation, isomerization and dehydrogenation of limonene and derivatives with supported palladium catalysts," Journal of Molecular Catalysis A: Chemical, vol. 148, no. 1-2, pp. 203-221, 1999.

[28] F. N. William, "Derivatives of (+)-Limonene. I. Esters of trans-p-Menthane-1,2-dio11," Journal of Organic Chemistry, vol. 23, no. 9, pp. 1274-1276, 1958.

[29] G. Rubulotta, K. L. Luska, C. A. Urbina-Blanco et al., "Highly selective hydrogenation of $\mathrm{R}-(+)$-Limonene to (+)-p-1Menthene in batch and continuous flow reactors," ACS Sustainable Chemistry \& Engineering, vol. 5, no. 5, pp. 3762-3767, 2017.

[30] C. R. Chang, Y. F. Zhao, B. Long, Z. Q. Huang, and J. Li, "On the catalytic role of water in chemical reactions: an overview," Scientia Sinica Chimica, vol. 46, no. 1, pp. 1-11, 2016.

[31] R. N. Butler and A. G. Coyne, "Water: nature's reaction enforcer-comparative effects for organic synthesis "in-water" and "On-Water"” Chemical Reviews, vol. 110, no. 10, pp. 6302-6337, 2010.

[32] S. Maier and M. Salmeron, "How does water wet a surface?" Accounts of Chemical Research, vol. 48, no. 10, pp. 2783-2790, 2015.

[33] T. K. Shimizu, A. Mugarza, J. I. Cerdá et al., "Surface species formed by the adsorption and dissociation of water molecules on a $\mathrm{Ru}(0001)$ surface containing a small coverage of carbon atoms studied by scanning tunneling microscopy," The Journal of Physical Chemistry C, vol. 112, no. 19, pp. 74457454, 2008.

[34] T. Mitsui, M. K. Rose, E. Fomin et al., "Water diffusion and clustering on $\operatorname{Pd}(111), "$ Science, vol. 297, no. 5588, pp. 1850-1852, 2002.

[35] S. Maier, I. Stass, J. I. Cerdá, and M. Salmeron, "Unveiling the mechanism of water partial dissociation on Ru (0001)," Physical Review Letters, vol. 112, no. 12, Article ID 126101, 2014.

[36] R. J. Buszek, J. S. Francisco, and J. M. Anglada, "Water effects on atmospheric reactions," International Reviews in Physical Chemistry, vol. 30, no. 3, pp. 335-369, 2011.

[37] L. Tianxiang, Z. Yongming, Z. Hongxi et al., "Facile Pdcatalyzed chemoselective transfer hydrogenation of olefins using formic acid in water," Tetrahedron Letters, vol. 57, no. 43, pp. 4845-4849, 2016.

[38] Y. Aritomo, S. Osamu, M. Naoki et al., "Direct production of sugar alcohols from wood chips using supported platinum catalysts in water," Catalysis Communications, vol. 54, pp. 22-26, 2014.

[39] A. T. Manoj and V. M. Vijaykumar, "Kinetics of hydrogenation of palm stearin fatty acid over $\mathrm{Ru} / \mathrm{Al}_{2} \mathrm{O}_{3}$ catalyst in 
presence of small quantity of water," Indian Journal of Chemical Technology, vol. 14, no. 1, pp. 52-63, 2007.

[40] T. N. Gieshoff, M. Villa, A. Welther et al., "Iron-catalyzed olefin hydrogenation at 1 bar $\mathrm{H}_{2}$ with a $\mathrm{FeCl}_{3}-\mathrm{LiAlH}_{4}$ catalyst," Green Chemistry, vol. 17, no. 3, pp. 1408-1413, 2015.

[41] D. R. Kennedy, G. Webb, S. D. Jackson, and D. Lennon, "Propyne hydrogenation over alumina-supported palladium and platinum catalysts," Applied Catalysis A: General, vol. 259, no. 1, pp. 109-120, 2004.

[42] R. L. Flesner and J. L. Falconer, "The role of spillover in carbon monoxide hydrogenation over alumina-supported platinum," Journal of Catalysis, vol. 139, no. 2, pp. 421-434, 1993.

[43] M. Katarzyna, T. Kin, and E. T. Shik Chi, "Comparison of catalytic performance of supported ruthenium and rhodium for hydrogenation of 9-ethylcarbazole for hydrogen storage applications," Energy \& Environment Science, vol. 5, no. 9, p. $8621,2012$.

[44] M. M. Stalzer, C. P. Nicholas, A. Bhattacharyya, A. Motta, M. Delferro, and T. J. Marks, "Single-Face/All-cis arene hydrogenation by a supported single-site $\mathrm{d} 0$ organozirconium catalyst," Angewandte Chemie International Edition, vol. 55, no. 17, pp. 5263-5267, 2016. 